\title{
Powieść w poszukiwaniu samej siebie: morfologia historyczna ${ }^{1}$
}

The Novel in Search of Itself: A Historical Morphology

\section{TEZA}

Powieść, podobnie jak epos i tragedia, opowiada o relacjach człowieka z otaczającym go światem. Jednak podczas gdy bohaterowie epopei bez reszty przynależą do swych miast, zaś los bohatera tragicznego jest z góry określony, powieściowi protagoniści zostają odseparowani od swojego świata, którego przygodność znajduje odzwierciedlenie w ich losie. Zrywając związki bohatera z otoczeniem, powieść staje się pierwszym gatunkiem poddającym refleksji genezę jednostki i ustanowienie powszechnej moralności. Nade wszystko powieść z niezwykłą precyzją stawia filozoficzne pytanie, czy ideały moralne są integralnym elementem świata. Jeśli tak, to dlaczego wydają się tak odległe od ludzkiego postępowania, a jeśli nie, to dlaczego tak jednoznacznie narzuca się nam ich normatywna wartość? W wypadku powieści podniesienie tej kwestii oznacza pytanie, czy broniąc swoich ideałów, ludzie powinni się przeciwstawić światu, zaangażować się w obronę ładu moralnego, czy też skupić się na naprawie własnych słabości. Rozważając te zagadnienia, powieść tradycyjnie koncentrowała się na miłości i łączeniu się ludzi w pary. Podczas gdy epos i tragedia przyjmowały jako oczywiste istnienie związków między jednostkami a ich środowiskiem, powieść koncentruje się na miłości, by poddać refleksji najbardziej intymną, interpersonalną postać, jaką owe związki przyjmują.

${ }^{1}$ Artykuł ukazał się pierwotnie w tomie Il romanzo, t. 2: Le forme, red. F. Moretti, Torino 2002. Przekład polski w niniejszym numerze na podstawie anglojęzycznej wersji artykułu, opublikowanej [w:] The Novel, t. 2: Forms and Themes, red. F. Moretti, Princeton, Oxford 2006. 
Powieść przednowożytna podkreśla prymat idei, która jest ważniejsza od obserwacji świata empirycznego. Ta właściwość wpływa zarówno na przesłanie, jak i na cechy formalne bardzo wyspecjalizowanych narracyjnych odmian gatunkowych. Niektóre z nich, takie jak grecka powieść albo romans pastoralny czy rycerski, przedstawiały bohaterów niezwyciężonych lub przynajmniej godnych podziwu, broniących norm moralnych w świecie pogrążonym w chaosie. Inne odmiany, takie jak narracja elegijna, łotrzykowska czy nowela, ukazywały nieusuwalną niedoskonałość istot ludzkich. W XVI i XVII wieku dialog między idealizacją a potępieniem ludzkich słabości miał postać pokojowej koegzystencji rozmaitych odmian gatunkowych.

Natomiast powieść osiemnasto- i dziewiętnastowieczna, która wyrosła ze zlania się wcześniejszych narracyjnych odmian gatunkowych, dążyła do zespolenia ich odmiennych perspektyw i połączenia idealizującej wizji z wnikliwą obserwacją niedoskonałości człowieka. Powieść osiemnastowieczna, która przyznawała prymat prawdopodobieństwu, pytała, czy ludzie są źródłem prawa moralnego i panami własnych działań. Powieściopisarze dziewiętnastowieczni konkludowali, że istoty ludzkie są kształtowane nie tyle przez normy moralne, ile przez środowisko społeczne i historyczne. By to udowodnić, skupiali się na skrupulatnej obserwacji świata społecznego i fizycznego oraz na empatycznej analizie sumienia jednostki. Dzięki temu gatunek osiągnął nowe możliwości i większą siłę, kosztem formalnej i tematycznej elastyczności wcześniejszych form narracyjnych.

Na początku XX stulecia moderniści wystąpili przeciwko zarówno próbom uwięzienia ludzkich istot w środowisku społecznym, jak i metodzie obserwacji i empatii. Ten bunt zaowocował bezprecedensowym rozziewem między jednostką uwolnioną od względów moralnych i pojmowaną jako miejsce niepoddającej się kontroli aktywności sensorycznej i językowej, a rzeczywistością, którą zaczęto postrzegać jako tajemniczą i głęboko niepokojącą. Modernizm nadał powieści nową dynamikę formalną, wciąż jednak skupiając się na jednostce i jej relacji z otaczającym światem.

\section{Od początków powieści do końca siedemnastego wieku}

\section{Przygoda i idealizacja: powieści greckie i romans rycerski}

Grecka powieść idealistyczna, którą ponownie odkryto i przetłumaczono na języki nowożytne w połowie XVI wieku, opowiada zwykle historię pary kochanków, którzy dzięki sile moralnej stopniowo pokonują przeszkody stojące na drodze do szczęścia. Wyróżnieni na tle otaczającego świata i kierujący się wyłącznie wzajemną miłością bohaterowie doświadczają wielu ciężkich prób 
symbolizujących niesprawiedliwość świata. W końcu jednak podstępy losu zostają przezwyciężone i powieść kończy się świętymi zaślubinami podkreślającymi wyjątkowe przeznaczenie bohaterów.

Powieść grecka podkreśla jedność rodzaju ludzkiego bytującego pod opieką opatrzności. W Opowieści etiopskiej Heliodora główna bohaterka, Charykleja, od urodzenia kwestionuje różnice rasy i środowiska. Wśród trzech mężczyzn, których nazywa „ojcami”, życie zawdzięcza Etiopczykowi Hydaspesowi, wykształcenie Grekowi Charyklesowi, a powołanie Egipcjaninowi Kalazyrysowi, wędrownemu kapłanowi z Memfis. W rzeczywistości pochodzi od bogów, a jej święty rodowód dominuje nad ludzką genealogią, tak jak jedność świata nad różnicami rasy.

Koncepcja uniwersalnego człowieczeństwa nie tylko pomniejsza znaczenie związków krwi, lecz także sprawia, że wychodźstwo staje się czymś wyobrażalnym. Wspominaliśmy wcześniej, że epos przedstawia bohaterów silnie zakorzenionych w rodzinnej ziemi. Bohaterowie tragiczni kwestionują niekiedy obowiązek wobec własnego miasta, by potwierdzić nadrzędność powinności religijnych (najbardziej znanym przykładem jest tu Antygona), niemniej jednak tragedie przedstawiają świat ograniczony murami greckiego polis. Grecka powieść odrzuca natomiast zarówno związki krwi, jak i miłość do ojczyzny. Charykleja, urodzona w Etiopii i wychowana w Grecji, chętnie opuszcza kraj swej młodości posłuszna boskiemu wezwaniu, które jest silniejsze od wszelkich innych powinności. Jej narzeczony, Teagenes, pochodzący z Tesalii potomek Achillesa, także bez wahania podąża za ukochaną do serca Afryki.

Gdy bohaterowie porzucają rodzinę i miasto, stają wobec niezmierzonego świata, który jest zarazem zaskakujący i wrogi. Niebezpieczeństwa rozrzucone na szlaku wędrówki pary młodych ludzi łączą się w jedną wielką niedolę, która towarzyszy im bez przerwy, nie dając chwili wytchnienia. Co prawda Teagenes i Charykleja obdarzeni są nadprzyrodzoną urodą, będącą znakiem wybrania przez bogów i budzącą nieustannie pożądanie i inne niegodziwe pragnienia. Prześladowani przez plugawe namiętności kochankowie pozostają jednak wierni sobie nawzajem, a ich cnota stanowi doczesną postać uświęcenia, które łączy ich ciała, ponieważ boskie aspiracje już wcześniej zjednoczyły ich dusze.

Piękni, czyści i lojalni bohaterowie greckich powieści są także nieugięci. Katastrofy morskie, niewola, rozłączenie, prześladowania, więzienie, tortury i stos pogrzebowy nie mają wpływu na te istoty lśniące niczym diament i niezłomne niczym stal. Ich niekończące się nieszczęścia ukazują świat jako padół łez, którego niesprawiedliwości należy się obawiać, a pokus - unikać. Niczym stoiccy mędrcy bezpiecznie skryci w swych wewnętrznych fortecach para pozostaje nieczuła na doznane cierpienia i zmiany losu. Dlatego nie ma sensu ubolewać nad brakiem w greckich powieściach elementu psychicznego dojrzewania, jak to niekiedy czynili krytycy. Powodem bohaterów do chwały jest właśnie ich niezmienność. 
Rzeczywistość greckich powieści rozgrywa się zatem między dwoma biegunami. Po jednej stronie jest oddzielona od świata opatrzność; po drugiej zaś jej korelat - nienaruszalna przestrzeń wewnątrz istot ludzkich. Odzwierciedleniem kosmicznej mocy boskości jest niezłomność ludzkiej duszy, jakby te dwie duchowe istności sprzymierzyły się przeciwko siłom, które próbują je rozdzielić: rzeczywistości fizycznej i społeczeństwu. Polegający na tym aliansie predestynowani kochankowie nie należą w pełni do tego świata i przyglądają się tej dziedzinie powstawania i ginięcia z boskim spokojem i dystansem. Spoglądają bowiem na ludzki świat ze szczególnej, niespodziewanej perspektywy - sub specie divinitatis - wyraźnie dostrzegając jego przygodność. Jeśli zatem grecka powieść tak często przedstawia kaprysy losu, nie dzieje się tak dlatego, że autorom brakuje wyobraźni lub nie zdołali uchwycić rzeczywistych odmian ludzkiej egzystencji. Przypadkowa sekwencja przygód - katastrof morskich, porwań, prześladowań - stanowi odzwierciedlenie fundamentalnej opozycji między parą polegającą na tym, co boskie, a światem, którym rządzi przypadek.

Romanse rycerskie, które czytywano powszechnie jeszcze w XVI i w XVII wieku, w mniejszym stopniu niż greckie powieści polegają na monoteistycznej koncepcji świata i przyznają boskości mniejszą rolę. W swych podróżach i zmaganiach błędny rycerz czerpie siłę nade wszystko z norm, których rygorystycznie przestrzega. Wcielając w życie bezwarunkowy obowiązek zachowania sprawiedliwości, poświęca się przywracaniu ładu i wydatkuje energię zgodnie z przyjętymi dobrowolnie zasadami rycerskości i dworskości. Zasady te wymagają aktywnego mierzenia się ze światem, a nie zjednoczenia z bóstwem; wymagają solidarności z innymi członkami społeczeństwa, a nie zabiegania o osobiste zbawienie.

Romanse rycerskie generalnie, a Amadis z Walii w szczególności, przedstawiają zdecentralizowane społeczeństwo, w którym lokalni panowie egzekwują swą władzę z dala od króla. Idealne zarządzanie tym systemem wymaga, aby silni chronili słabych, cieszący się powodzeniem nieśli otuchę dotkniętym przez los, a ludzie dobrej wiary wystrzegali się zdrady. Wcielanie w życie tego ideału w całej różnorodności sytuacji społecznych rodzi problemy, ponieważ przy braku ciagłej władzy centralnej nieustannie pojawiają się zarzewia przemocy. Rycerze gorączkowo przemierzają kraj, gasząc je i przywracając rządy prawa. Lokalny, ograniczony charakter naruszeń sprzyja szybkim środkom zaradczym, które jednak zawsze przypadkowe i fragmentaryczne nie prowadzą do decydującej batalii i trwałego przywrócenia ładu.

Rycerze narażają zatem życie, broniąc norm, które nieustannie są zagrożone. Konkretny przypadek owego zagrożenia to przygoda. Dzień i noc, w zamku, przy okrągłym stole czy na trakcie, rycerze trwają w czujności, czekając na wezwanie. Gdy ktoś prosi o pomoc, śluby zobowiązują rycerza, by natychmiast opuścił przyjaciół, rodzinę i króla (tudzież ramiona ukochanej), dosiadł rumaka i ruszył do walki. Ten obowiązek opatrzony jest podwójnym rygorem. Rycerz musi strzec swego honoru, który najmniejszy przejaw tchórzostwa skalałby bezpowrotnie. Ponadto rycerza łączy z przygodami tajemniczy, osobisty 
związek. Tajemnymi wyrokami przeznaczenia określone śmiałe przedsięwzięcie przynależy określonemu rycerzowi i tylko on może - i musi - je podjąć.

Epizodyczna, powtarzalna natura rycerskich opowieści podlega zasadzie odmiennej od tej, która rządzi grecką powieścią. W Opowieści etiopskiej pozornie przypadkowa sekwencja przygód w ostatecznym rozrachunku symbolizuje rozziew między światem życia codziennego a silną duszą, która poświęca się miłości i Bogu. W romansach rycerskich natomiast czekające bohatera i jego towarzyszy broni niekończące się ciężkie próby przypieczętowują trwałe przymierze między tymi bohaterami a światem, który nieustannie starają się chronić w zgodzie z wyznawanymi normami moralnymi.

W romansach tych źródłem mocy pary, której znakiem jest dworski obowiązek, nie jest już boskie powołanie jak w modelu greckim. Para czerpie moc z siebie, a mówiąc dokładniej z mocy damy. To prowadzi do paradoksu. Z jednej strony obraz pięknej Oriany, damy Amadisa, jest obrazem prawdziwego bóstwa, które rycerz przywołuje zawsze, gdy jest w niebezpieczeństwie, z drugiej strony miłość dwojga bohaterów jest rezultatem czysto ludzkiej decyzji partnerów, którzy wybierają siebie samodzielnie, z nikim tego nie konsultując. Dama daje wojownikowi siłę, zapewniając mu idealny cel, do którego może dążyć. Jednocześnie oddając się potajemnie kochankowi, przypieczętowuje niezależność pary od jakiejkolwiek mocy zewnętrznej.

Rycerzowi i jego damie zostaje w ten sposób nadana transcendentna władza - nawet gdy muszą realizować określone zadania społeczne. Oznacza to, że włączeni w cykl ziemskich przygód, w którym ich człowieczeństwo poddaje ich przeciwnościom i pokusom, zostają zarazem przeniesieni na niebieską orbitę, skąd niezwyciężeni i niezniszczalni wywierają wpływ na przeznaczenie innych śmiertelników. Sławienie nadludzkiej mocy rycerza i ubóstwienie damy to efektywny sposób stworzenia transcendencji środkami czysto ludzkimi. W ten sposób, mimo symbolicznej asymetrii, dworska miłość wspiera normy rycerskości. Łącznie tworzą ideał, którego pochodzenie zostało zamknięte w granicach tego, co ludzkie.

\section{Niedoskonałość i świat życia codziennego: romans pastoralny i powieść łotrzykowska}

Pierwotnie romans pastoralny nie należał do rodziny dzieł silnie idealizujących, którą tworzyły powieści greckie i romanse rycerskie. Pierwszy przykład tego gatunku, Dafnis i Chloe Longosa, to krótka narracja opowiadająca o wydarzeniach rozgrywających się w skromnej wiosce, a nie w całym znanym świecie. Przedstawia postaci, które nie tylko nie rzucają wyzwania światu społecznemu, ale wręcz aspirują do tego, by do niego dołączyć. Postaci te, pokrewne bohaterom komedii, rozkwitają w łasce idyllicznej miłości i radośnie odkrywają 
zrównoważoną zmysłowość, odrzucając okrucieństwo i przemoc. Dużo później Arcadia Jacopa Sannazaro (1501) i Diana Jorge de Montemayora (1559) dopełniły motyw dojrzewania pełnego wahań i wdzięku nutką melancholii.

Już wkrótce jednak romans pastoralny znalazł się pod wpływem greckiej powieści idealistycznej i romansów rycerskich. Sir Philip Sidney w Arcadii (1580) i Honoré d'Urfé w Astrei (1607-1627) zaproponowali syntezę elegancji romansu pastoralnego i idealizacji rodem z powieści przygodowych. Dzieła te głoszą zdecydowaną afirmację transcendentnych ideałów, a zarazem przedstawiają stopniowe odkrywanie samego siebie poprzez miłość. Zwłaszcza Astrea nie jest zwykłym romansem pastoralnym, lecz stanowi oryginalną syntezę sielankowego przedstawienia ludzkich ułomności z idealizmem, który kieruje życiem bohaterów greckich i rycerskich.

Akcję Astrei uruchamia nieporozumienie między dwojgiem głównych bohaterów - Celadonem i Astreą, kłótnia, która podkreśla kruchość miłości. Nawet miłość połączona z największym oddaniem - jak ta Celadona i Astrei - jest równie podatna na kaprysy jak najbardziej ulotne uczucia. Astrea, podobnie jak każdym sielankowym światem, rządzi nieuchronna dysproporcja między ideałem miłości a postępowaniem konkretnych par. W tym przypadku kochankowie zostają rozdzieleni z własnej winy, a główny wątek prowadzi do ostatecznego triumfu ich prawdziwych uczuć. Miłość, zmuszając młodych pasterzy do odkupienia własnej niedoskonałości, destyluje z niej czysto niebiańską substancję. Metal nieszlachetny zmieniony w złoto pozostaje oczywiście materią jednak przeobrażona substancja staje się symbolicznie niezniszczalna.

Podczas gdy greccy powieściopisarze idealistyczni pojmowali jednostkę jako niezłomne „ja” sprzymierzone z wszechmocnym bóstwem, narracje pastoralne kreowały bardziej zniuansowany obraz ludzkiego wnętrza, skupiając się na rozłamie wewnątrz, ja” i jego stopniowym uzdrowieniu w toku dojrzewania bohatera. Sielankowi pasterze, niemający niezbędnych kwalifikacji, by odczytywać samych siebie czy zrozumieć tych, których kochają, wahają się między siłą swych pragnień a ideałami, które pragną realizować. Miłość napełnia ich pragnieniem doskonałości, nawet jeśli zarazem sprawia, że nie potrafią dostrzec sposobów jej osiągnięcia. Dopiero kiedy Celadon musi się przebrać za młodą kobietę, wznosi się w końcu ponad swój egoizm i zaczyna inaczej patrzeć na świat. Kiedy zapomina o sobie, pieczołowicie odgrywając rolę kobiety, udaje mu się opanować namiętność. Podobnie jak przebrani kochankowie w pochodzących z tego samego okresu komediach Szekspira Celadon uczy się uwalniać od instynktów i namiętności oraz przestrzegać ogólnej zasady, która jest - i musi pozostać - mu obca. Innymi słowy, uczy się przestrzegać norm.

Nie należy przeceniać podobieństw Astrei do nowożytnej Bildungsroman ani też zapominać o jeszcze jednym, nie tak rozpowszechnionym przednowożytnym podgatunku, także poświęconym rozwojowi osobowości, jakim jest opowieść o wychowaniu księcia oparta na modelu Wychowania Cyrusa Ksenofonta. Niemniej we wszystkich swoich wcieleniach romans pastoralny przedstawia 
proces dojrzewania jednostki i jej terminowania w dziedzinie norm społecznych. Powieści te nieustannie podkreślają, że „ja” jest gotowe przyjąć pochodzącą od społeczeństwa regułę postępowania, o ile tylko może jej swobodnie poszukiwać.

Powieść łotrzykowska jest najbardziej zjadliwym z gatunków poświęconych ludzkiej niedoskonałości. Wywodzi się z tradycji sięgającej korzeniami Petroniuszowych Satyryk i Złotego osta Apulejusza, która została następnie odnowiona w opowieściach Boccaccia, fabliaux i Powieści o lisie. Te dzieła wywołuja śmiech, ukazując kontrast między doniosłym ideałem a oczywistą niedoskonałością, która pozostaje z nim w sprzeczności. Począwszy od połowy XVI wieku nowy typ opowieści łotrzykowskiej stopniowo uwolnił się od śmiechu i świadomie zaczął się przypatrywać ludzkiej niedoskonałości z powagą, która wcześniej była zarezerwowana dla przedstawień doskonałości człowieka.

Najwcześniejszym przykładem tego gatunku jest Żywot tazika z Tormesu, anonimowe dzieło hiszpańskie wydane w latach 1553-1554. Młody bohater to uosobienie oszusta, typ sprytnego i pozbawionego skrupułów samotnika, który pojawia się we wszystkich tradycjach ustnych. Otaczający go świat jest bardzo jednorodny, podobny do świata przedstawianego przez greckie powieści idealistyczne. Wszyscy panowie Łazarza są równie niegodziwi, biedni i nieuczciwi. Już wcześniej zauważyliśmy, że powieść grecka i średniowieczna wykorzystywały strukturę epizodyczną nie dlatego, że autorzy z tych czy innych powodów nie potrafili skonstruować lepszej fabuły, lecz dlatego, że szukali najlepszego sposobu przedstawienia jednorodności i wrogości świata. W powieściach łotrzykowskich sekwencja epizodów pełni podobną funkcję. Niezależnie od wyniku określonego zdarzenia świat zawsze przytłacza Łazarza swą niewyczerpaną wrogością, jakby jego kolejni panowie byli (każdy na swój sposób) wcieleniami jakiegoś uniwersalnego zagrożenia.

W tej powieści zagrożenie jest dwojakie: dotyczy przetrwania postaci tu i teraz, jak również wzajemnego zaufania człowieka do człowieka. Na planie przetrwania Żywot tazika z Tormesu, podobnie jak więlkszość powieści pikarejskich, przedstawia ekonomię braku. Nieustanną troską bohatera jest znalezienie łóżka i wiktu. W swej walce ze skrajną biedą stanowi on odwrócone lustrzane odbicie walczących bohaterów powieści greckich. W Opowieści etiopskiej bohaterowie przemierzają lądy i morza w poszukiwaniu niebiańskiego pożywienia; tu Łazarz podróżuje przez Hiszpanię, wykorzystując swój spryt, żeby zdobyć okruszynę chleba i łyk wina. Prawdziwą tragedią pikarejskiego świata jest jednak destrukcja ładu moralnego i brak wzajemnego zaufania. W powieści łotrzykowskiej niemożliwa byłaby obrona transcendentnego prawa za pomocą środków czysto ludzkich. Pikaro odrzuca ideał rycerski.

Można mówić o dwóch odmiennych typach bohatera pikarejskiego. Jeden bez wyrzutów sumienia akceptuje amoralność swojej sytuacji; drugi, pikaro moralizujący, gardzi swym nędznym życiem w imię wyższego prawa, którego nie potrafi przestrzegać. W pierwszym wypadku bohater taki jak Łazarz postępuje wbrew normom moralnym i postrzega swe wykluczenie $\mathrm{z}$ domeny 
moralności jako stan naturalny. Ten amoralny pikaro jest w istocie szczęśliwym człowiekiem, który znajduje przyjemność w nabieraniu innych i rzadko snuje refleksje na temat norm, jakie powinny rządzić ludzką egzystencją. W amoralnej odmianie powieści pikarejskiej nieobecna jest świadomość transcendencji i ideałów moralnych. W rezultacie jej bohaterowie nie rozumieją w pełni, dlaczego w świecie jest tyle przypadku i zdrady. Nie pamiętają także utraconego, lepszego świata opartego na zaufaniu i sile moralnej, a więc w konsekwencji za nim nie lamentują.

Drugi typ bohatera pikarejskiego podejmuje natomiast przedsięwzięcia równie niemoralne jak przygody Łazarza czy bohaterów Quevedy, jednak w przeciwieństwie do nich nie akceptuje własnej nikczemności i nie rozgrzesza się z występków moralnych. Specjalistą w portretowaniu tego typu bohatera był purytanin Daniel Defoe. W powieściach Moll Flanders (1722) i Roksana, czyli szczęśliwa kochanka (1724) z bezprecedensową wyrazistością rozpatruje społeczny wymiar bohatera pikarejskiego i jego świata, uwydatnia moralne motywy gatunku i podkreśla wspólnotę - choć zawsze niepewną - przeznaczenia głównych bohaterów.

Stosunek Moll i Roksany do norm moralnych, które przekraczają, jest skomplikowany i często rodzi cierpienie. W wypadku bohaterów Defoe pragnienie przestrzegania norm - co w ich przypadku oznacza aspirowanie do małżeńskiego szczęścia - nie jest po prostu wynikiem wyrzutów sumienia czy tęsknoty za niewinnością, lecz staje się jedną z najważniejszych motywacji determinujących ich działania. Niemniej Moll czyni zło nie tylko z konieczności, lecz także za sprawą skłonności, i jest zaskoczona, gdy zdaje sobie sprawę z rozmiarów swego zepsucia. Niedoskonałość Roksany, przyjmująca jeszcze bardziej dramatyczną postać niż u Moll, prowadzi do katastrofy, gdy amoralna przeszłość powraca i zaczyna ją prześladować. Zdeterminowana, by zakończyć karierę kurtyzany (i byłej kochanki króla) i prowadzić uczciwe życie, Roksana widzi w powrocie córki, którą dużo wcześniej porzuciła, zagrożenie dla szczęścia wywalczonego z takim trudem. Aby zachować pozory cnoty i zapewnić sobie szacunek męża, Roksana nie może dopuścić do wyjawienia dwóch sekretów: porzucenia dziecka i związku z królem. Po serii halucynacyjnych scen staje się faktyczną współsprawczynią zabójstwa własnej córki.

Zwykle pikarejskim bohaterom boleśnie doświadczanym przez zbiegi okoliczności udaje się przetrwać, o ile potrafią się przystosować i unikają pułapki moralnej godności. W pełnym niespodzianek świecie, którym rządzi przypadek - a w takim właśnie rozgrywają się zarówno powieści łotrzykowskie, jak i idealistyczne - dostępne są jedynie dwie strategie. Jedna polega na przeciwstawieniu się światu w imię transcendentnej normy, czy to przez ucieczkę, czy przez narzucenie mu sprawiedliwości. Strategia druga polega na dostosowaniu się do niego za cenę moralnej niezależności. Cechująca Roksanę nietypowa wewnętrzna siła i dążenie do autonomii wnosi w lekkość pikarejskiego świata ciężar powagi i wprowadza spójność w jego przypadkowe epizody. Podkreślając 
wagę ludzkich występków i niezmywalność dawnych grzechów, Roksana stanowi pełną realizację powieści pikarejskiej, a tym samym wyznacza jej logiczny kres.

\section{Uwagi o metodzie ideograficznej}

Mimo różnic wszystkie typy powieści idealistycznej łączą istotne cechy. Ich realizm nie wynika stąd, że przedstawiają rzeczywistość znaną czytelnikowi. Skłaniają go natomiast do uchwycenia idei jednoczącej ich wyimaginowane światy, idei radykalnego rozziewu między ludzkim światem a bohaterem, który rozumie transcendentność norm moralnych. (Może to prowadzić czytelnika do refleksji, czy idea ta nie pomaga lepiej zrozumieć także świata realnego). Opierając się na tej teoretycznej wizji, powieści idealistyczne pracowicie konstruują fikcyjny świat, który jest bardzo odmienny od świata życia codziennego, i przedstawiają go jako spójną całość. Zgodnie z tą metodą, którą można by nazwać ideograficzną, wyimaginowany świat jest kształtowany przez jedną abstrakcyjną ideę, którą nieustająco ilustrują liczne epizody.

Ponieważ powieści te generuje abstrakcyjna idea, brak im prawdopodobieństwa. Zarówno bohaterowie, jak i miejsca są poddane idealizacji z akcentem na najważniejsze cechy - niezłomność Cheraklei, wielkoduszną dzielność Amadisa, lecz także pożądliwość i okrucieństwo Arsake czy przewrotność czarnoksiężnika Arkalausa - kosztem cech drugorzędnych, które pozostają nierozwinięte. Nacisk na cechy istotne przy jednoczesnym pomijaniu cech przygodnych skutkuje powstaniem postaci relatywnie ubogich we właściwości, których główne atrybuty są obecne z wyjątkową intensywnością. Ponieważ w powieściach idealistycznych główna idea rozwija się zarówno w czasie, jak i w przestrzeni, fabuła takich powieści jest z konieczności epizodyczna. To wyjaśnia duracyjny ich charakter i panoramiczną naturę ich akcji. I wreszcie, narracja powieści idealistycznej jest zwykle trzecioosobowa, jakby miała przekazać obiektywną moc obowiązywania fundamentalnej idei.

Powieści łotrzykowskie na swój własny sposób podtrzymują tradycję ideograficzną niejako à rebours, ponieważ istoty wyjątkowe zastępują jednostkami ze skazą. Podobnie jak powieści idealistyczne powieści pikarejskie poprzez liczne epizody starają się ewokować abstrakcyjną ideę: radykalny rozdział między światem a tymi jednostkami, które nie są zdolne dostosować się do norm społecznych. Postaci te, podobnie jak godni naśladowania bohaterowie powieści greckich, średniowiecznych czy pastoralnych, są wytworem idealizacji w tym sensie, że ich cechy zostają zredukowane do istotnych właściwości zbieżnych z jednoczącym tematem powieści. Powieści łotrzykowskie, podobnie jak narracje idealistyczne, zawsze są duracyjne i panoramiczne, penetrują czas i przestrzeń w poszukiwaniu wzorcowych przypadków ucieleśnienia swej kluczowej idei. 
Powieść pikarejska dzieli z nimi te właściwości, jednak różni się od swych idealistycznych poprzedników pod dwoma względami. Jeden to nagromadzenie znanych szczegółów z życia codziennego; drugi - narracja pierwszoosobowa mająca charakter świadectwa. Należy przy tym podkreślić, że obie te właściwości mają uwydatnić ideograficzne przedstawienie zepsutego świata, a nie ewokować jego historyczną i społeczną specyfikę. W powieściach łotrzykowskich znane szczegóły mają wskazywać konkretność poszczególnych przypadków niedoskonałości pozostających w służbie ogólnej, jednoczącej idei powieści. Także pierwszoosobowa narracja służy podkreśleniu niedostatków bohaterów, których działania są tak poniżające dla nich samych, że nikt inny nie pomyślałby nawet, by o nich opowiedzieć. W Opowieści etiopskiej nagromadzenie nieoczekiwanych przygód i relacja w trzeciej osobie zachęcają czytelnika do refleksji nad ogólnym sensem ludzkiej kondycji. Podobnie w Żyocie tazika i Moll Flanders konfesyjny ton i znajome przedmioty istnieją nie po to, aby zapewnić wierne przedstawienie rzeczywistości (ponieważ powieści łotrzykowskie są równie nierealistyczne jak powieści greckie i rycerskie), lecz jako ilustracja abstrakcyjnej hipotezy dotyczącej moralnej istoty świata.

\section{Narracje elegijne}

Podobnie jak gatunki ideograficzne narracje elegijne i nowele skupiają się na określonych sytuacjach, aby uwydatnić jasno sprecyzowane idee, na przykład daremność miłości czy niebezpieczeństwo ciekawości. W tych podgatunkach wybrana idea ma jednak bardziej ograniczony zakres, co zostaje wykazane indukcyjnie na jednym wzorcowym przykładzie.

Narracja elegijna, sukcesorka Heroid Owidiusza, a także być może Wyznań św. Augustyna, jest pierwszoosobowym lamentem nad uczuciowymi nieszczęściami głównego bohatera. Najbardziej znane przykłady to Fiametta Boccaccia (1344-1345) i Listy portugalskie Guilleraguesa (1669). Fabuła opowiada zwykle o nieszczęśliwej miłości nieżonatego mężczyzny i kobiety związanej przysięgą małżeńską lub ślubami religijnymi. Treścią dzieła jest skarga uwiedzionej, a następnie porzuconej kobiety. Przedmiotem narracji elegijnych jest życie wewnętrzne człowieka i jego wyjątkowość, życie wewnętrzne, które ewokuje liryczna ekspresja. Choć narracja elegijna zajmuje niewielką niszę pośród wielu przednowożytnych podgatunków narracyjnych, odegrała ważną rolę w osiemnastowiecznej rewaloryzacji introspekcji. 


\section{Nowele i rola indukcji}

Nowela, głęboko zakorzeniona w tradycjach ustnych, kwitła we Włoszech, Francji i w Hiszpanii od XIV do XVII wieku, czego dowodzą pochodzące z tego okresu zbiory prozy narracyjnej: Dekameron Boccaccia (powstał po 1350 roku), Nowele Mattea Bandella (1554), Heptameron Małgorzaty z Nawarry (1559), Ecatommiti Cinzio Giraldiego (1559) czy Nowele przyktadne Cervantesa (1613). Nowela, podobnie jak powieść łotrzykowska, przypatruje się ludzkiej niedoskonałości, zamiast jednak prezentować ją w postaci ogólnej, abstrakcyjnej hipotezy, której prawdziwości ma dowieść seria przykładów, ukazuje ją jako prawdę objawiającą się w szczytowym momencie akcji. Ulubionym tematem noweli jest przepaść dzieląca jednostkę od jej środowiska, która jednak - inaczej niż w powieściach łotrzykowskich - nie istnieje uprzednio. Jest raczej rezultatem działań głównych bohaterów, którzy ostatecznie separują się od swojej społeczności z wyboru lub zostają z niej wykluczeni.

W przeciwieństwie do duracyjnej i panoramicznej fabuły powieści idealistycznej, której czytelnicy mogą się cieszyć długą znajomością z postaciami, nowele zorganizowane są wokół pojedynczego, zaskakującego wydarzenia, którego okoliczności są ledwie naszkicowane, choć zakłada się jego realność. Podczas gdy powieści idealistyczne wymagają od czytelnika zawieszenia niewiary, nowela pragnie zapewnić gwałtowne, przemożne poczucie realności i utrzymuje, że przedstawia wydarzenia należące do świata rzeczywistego. Wiarygodne okoliczności nie są jedynie reakcją na idealistyczną ideografię, lecz stanowią niezbędny warunek osiagnnięcia przez nowelę zakładanego celu.

Przedstawienie pojedynczego, znamiennego wydarzenia osadzonego w prawdopodobnych realiach może prowadzić do interpretacji poważnej lub komicznej, w zależności od natury samego wydarzenia. Założenie, że przedstawione wydarzenia należą do świata rzeczywistego, niewątpliwie pomaga osiągnąć nowelom komicznym zamierzony cel, ponieważ komizm wiąże się zwykle z poczuciem konkretności przedstawionej rzeczywistości. W nowelach poważnych i tragicznych natomiast szlachetność tematu często sprzyja idealizacji i przedstawieniu fikcyjnego świata odmiennego od realnej rzeczywistości. Dlatego właśnie niektóre poważne nowele, których tematem jest arbitralne okrucieństwo losu i niezłomna cnota bohaterów (np. opowieść o Gryzeldzie w Dekameronie Boccaccia, 10.10) bardzo przypominają skrócone powieści idealistyczne. Podobieństwo to podkreśla podstawowe wyzwanie, jakiemu muszą stawić czoło poważne i tragiczne nowele: jak zapewnić prawdopodobieństwo, unikając zarówno technik literatury komicznej, jak i powieści idealistycznych.

Należy zatem rozróżnić dwa sposoby kreowania wrażenia prawdopodobieństwa. $Z$ jednej strony można je osiągnąć na poziomie treści i wtedy bierze się ono z podobieństwa między światem przedstawionym a światem, który 
uznajemy za rzeczywisty. Tego rodzaju prawdopodobieństwo generuje realizm moralny, jak w poważnych nowelach, i realizm społeczny, jak w dziewiętnastowiecznych powieściach. $Z$ drugiej strony efekt prawdopodobieństwa może pochodzić od określonych detali, które sprawiają, że świat przedstawiony cechuje żywa obrazowość. Realizm deskryptywny daje czytelnikom poczucie zanurzenia w świecie przedstawionym. Temat mitologiczny, skrajnie daleki od naszego doświadczenia, może zostać ujęty w narracji posługującej się bogatym, zmysłowym i nasyconym szczegółami językiem, który pomaga wywołać efekt zanurzenia. $Z$ kolei do tematu wziętego z życia codziennego i ujętego według zasad realizmu moralnego można zastosować styl surowy, który skrupulatnie unika konkretnych szczegółów zmysłowych.

Moralny realizm przednowożytnej noweli przedstawia jednostki, które są w pełni zależne od innych, a jednocześnie nie potrafią podporządkować swych namiętności i interesów władczym wymaganiom czujnego społeczeństwa. Psychologia moralna bohaterów zależy od tego, jakiego rodzaju przeciwnościom przyszło im stawić czoło. Niekiedy stykają się z widocznymi przeciwnościami zewnętrznymi: oporem rodziny wobec małżeństwa, niewiernością małżonków i kochanków, kaprysami losu. W tego rodzaju sytuacjach bohaterowie działają jako antagoniści, występując przeciwko zagrażającym im siłom. Innego rodzaju przeciwności prześladują ofiary podstępu. Postaci tego rodzaju, których reprezentantem jest Maur wenecki, podlegają manipulacjom wrogów podających się za sojuszników. W tym wypadku mamy do czynienia z ukrytymi przeciwnościami zewnętrznymi, a nieświadomy niczego bohater staje się narzędziem sił zła i przyczyną własnego upadku. Widoczne przeciwności wewnętrzne to niewinne lub nieczyste namiętności będące źródłem konfliktu bohatera z otoczeniem. Choć w literaturze sprzed XVIII wieku nie znajdujemy prawdziwych ukrytych przeciwności wewnętrznych - namiętności powodujących bohaterami bez ich wiedzy - autorzy siedemnastowiecznych nowel, a w szczególności Cervantes w Nierozważnej ciekawości i Madame de La Fayette w Księżnej de Clèves (dzieło to zalicza się dziś do powieści, choć współcześni uznawali je za nowelę), zgłębiają tajniki realizmu moralnego, badając widoczne, lecz niepojęte przeciwności wewnętrzne mające postać namiętności, których natura i cel pozostają niezrozumiałe dla głównego bohatera. Podczas gdy nowele włoskie (a także większość hiszpańskich) przedstawiają życie wewnętrzne postaci zgodnie z siatką powszechnie przyjętych motywacji i można je określić mianem „kazuistycznych” noweli psychologicznych, nowele, które można nazwać „augustyńskimi”, badają tajemniczą siłę namiętności i straszliwe skutki zaślepienia. 


\section{Osiemnaste stulecie i narodziny powieści nowożytnej}

W ciągu XVIII stulecia narracyjny idealizm przeszedł głębokie przeobrażenie. Normy moralne przestano postrzegać jako transcendentne i przyjęto, że zamieszkują one serce człowieka. Owej interioryzacji ideału dokonali w imię prawdopodobieństwa Samuel Richardson i Jean-Jacques Rousseau. Wzbudziło to zdecydowany sprzeciw i pośrednio doprowadziło do odnowienia sceptycznej i komicznej wizji ludzkiej niedoskonałości, czego przykładem jest proza narracyjna Henry'ego Fieldinga. Spór tych dwóch wizji sprzyjał powstawaniu kolejnych formuł narracyjnych, w tym powieści ludycznych i gotyckich, powieści sentymentalnej i powieści obyczajowej.

\section{Powieści epistolarne i nowy idealizm}

W XVIII stuleciu zarówno powieść, jak i filozofia moralna przyczyniły się do powstania nowego ideału ludzkiej doskonałości: pięknej duszy. Był on kolejną odpowiedzią na odwieczne pytanie aksjologiczne, a zarazem źródłem nowej koncepcji miłości. Jak już wspominaliśmy, pytanie aksjologiczne brzmiało: jeśli ideał moralny przynależy do świata ludzkiego, dlaczego wydaje się tak nieosiągalny, a jeśli do niego nie przynależy, to czemu każdy tak wyraźnie czuje jego normatywną wagę? W okresie przednowożytnym przyjmowano, że wartości moralne mają swe źródło poza sferą tego, co ludzkie, i sytuowano ideał z dala od świata życia codziennego, w dziedzinie, która była zarówno zewnętrzna, jak i nadrzędna. Istoty ludzkie mogły się poddać swej niedoskonałości albo postępować heroicznie, wzorując się na ideale. Za wzorzec doskonałości człowieka służyły dusze, które zdołały uchwycić światło norm moralnych i wzmocnić je niczym wielki reflektor.

Powieść osiemnastowieczna ponownie postawiła pytanie aksjologiczne i zaproponowała nową odpowiedź, wpisującą ideały moralne w ludzkie serce. Uznano, że dusza, która zgodnie z dawnymi przeświadczeniami miała postępować wedle norm moralnych pochodzących z góry, zawiera w sobie (i potrafi rozszyfrować) wieczne prawidła moralnej doskonałości. W następstwie tego, co moglibyśmy nazwać interioryzacją ideału lub też zaczarowaniem wnętrza, wszystkie istoty ludzkie, nawet te najzwyklejsze, uznano za zdolne do poszukiwania wewnętrznej doskonałości, a jako piękne dusze określono te, którym owe poszukiwania zawsze udaje się uwieńczyć sukcesem.

Interioryzacja moralności oznaczała, że cnotliwych istot nie trzeba już było szukać w wyimaginowanej sferze idealnej. Jeśli istoty moralne chodziły po ziemi, cały świat życia codziennego nabierał wartości współmiernej z ich wartością. W osiemnastowiecznych powieściach piękne dusze nie czują się już zmuszone 
odseparować się od innych istot ludzkich: ich wewnętrzna szlachetność wystarczająco wyróżnia je niejako in situ. Ponieważ przeznaczeniem tych postaci było kochać, cierpieć i jaśnieć pośród równych sobie, nowożytna powieść idealistyczna nie potrzebowała wędrówek i epizodycznego rozproszenia, które charakteryzowały starożytną odmianę tego gatunku. Zamiast tego nowożytne narracje zagłębiały się w sferę subiektywności postaci, a także opisywały z wielką precyzją ich społeczne i fizyczne otoczenie.

Ponieważ poważne nowele już wcześniej zgłębiały tajniki moralności, bliskie relacje wiążące jednostki ze społeczeństwem, a w pewnych przypadkach również ich fizyczne otoczenie, właśnie ten narracyjny podgatunek stał się szkołą dla osiemnastowiecznych powieściopisarzy. Badając wewnętrzną doskonałość, a zarazem obiektywny świat, próbowali oni jednocześnie wyodrębnić idealne jednostki w ich pełnej świetności (specjalność starożytnych powieści) i wymyślić - na podobieństwo noweli - efektowne dramaty wynikające ze skomplikowanych przyczyn psychologicznych. Musieli zatem poradzić sobie z jednością akcji - techniką rozwijaną przez nowele, która pozwalała odróżnić je od długich, epizodycznych powieści.

Pierwszą powieścią, która z powodzeniem połączyła w jednej fabule szlachetność skromnego człowieka, bogactwo życia wewnętrznego, fizyczność świata i jedność akcji, była Pamela, czyli cnota nagrodzona Samuela Richardsona (1741). Udało się w niej stworzyć nową, sugestywną syntezę powieści idealistycznej, łotrzykowskiej i noweli. Zaproponowała nowe wcielenie cnotliwej heroiny, którą uwikłała w sekwencję epizodów zbiegającą się w jednym punkcie, wyposażając ją jednocześnie w ukrytą, znacznie bardziej moralną świadomość.

Pamela, potomkini heroin powieści idealistycznych, jest strzeżoną przez opatrzność istotą z innego świata, nieugiętą, zdolną przetrwać wszelkie przeciwności. Jej pochodzenie może być skromne, lecz podobnie jak w powieściach greckich wyjątkowa uroda jest widzialnym znakiem quasi-boskiego statusu. Niewzruszona cnota, niezłomność i mądrość Pameli zapowiadają, że jest ona niezależna od okoliczności, w których się znalazła. Jej korzenie, podobnie jak Charyklei, tkwią gdzie indziej. Zaczarowanie wnętrza nadaje sens narracji pierwszoosobowej. We wcześniejszych powieściach, gdzie ideał pojmowano jako zewnętrzny, bezosobowe właściwości czystości i nieugiętości jaśniały w oddali, podczas gdy sromota kryła się w zakamarkach duszy. Spoglądając na siebie, można było dostrzec jedynie nikczemność. Natomiast w dziele Richardsona, gdzie ideał emanuje z wnętrza, dusza bohaterki spontanicznie i skrycie promieniuje moralnym pięknem. Jedynie Pamela może o sobie opowiadać, ponieważ nikt z zewnątrz nie potrafi zrozumieć ani opisać nadzwyczajnej wrażliwości i siły, które kryją się w jej sercu.

Przedstawienie wszystkich wydarzeń z punktu widzenia Pameli wzmaga czytelnicze zainteresowanie akcją - zarówno w całości, jak i w jej niezliczonych epizodach. Jednym z wielkich odkryć Pameli jest sztuka naocznego ewokowania ludzkiego doświadczenia, także jako wewnętrznej gry zaślepienia, 
oczekiwania, udręki i nadziei. Dlatego deskryptywnego realizmu Richardsona nie można sprowadzać jedynie do świadectwa dotyczącego świata, jak gdyby czytelnicy byli ławą przysięgłych badającą dostępne fakty w poszukiwaniu przekonujących dowodów. Jest to również i nade wszystko sposób ukazania psychologii. Tego rodzaju realizm zanurza czytelnika w takim fikcyjnym świecie, jaki postrzega postać, pokazując jej życie wewnętrzne tym skuteczniej, że przedstawienie to ma charakter pośredni.

Za sprawą zaczarowania wnętrza wszystko, co postać widzi, słyszy lub czuje, staje się nieskończenie wartościowe i godne zainteresowania. Zaczarowanie przenika także - choć w sposób zawoalowany - nową, opisową technikę pisarską. Zamiast śladem poprzedników zmierzać bezpośrednio do sedna każdego wydarzenia Richardson prezentuje to, co bohaterka postrzega tu i teraz, a nie to, czego czytelnik mógłby potrzebować, aby zrozumieć rozwijającą się narrację. W świecie, w którym sumienie odgrywa tę rolę, którą kiedyś odgrywało bóstwo, perspektywa jednostki uświęca wszystko, co ona widzi, w tym rzeczy najbardziej niepozorne. $\mathrm{Z}$ tego powodu przedstawienie naocznego doświadczenia zaczęło powoli, lecz nieodparcie dominować w powieści, kosztem zrozumiałości i zwięzłości.

\section{Komedia ludzka czyli pojawienie się autora}

W Julii, czyli Nowej Heloizie (1749) Rousseau kontynuował i zradykalizował Richardsonowski sposób przedstawiania nowożytnej cnoty, niemal całkowicie opierając swoją narrację na zaczarowaniu wnętrza postaci. Z kolei Henry Fielding, który otwarcie krytykował projekt Richardsona, zdecydowanie odrzucił nowożytny idealizm. Jego zdaniem celem powieści nie jest nadanie nowożytnego oblicza wyimaginowanej cnocie starożytnych bohaterów, lecz uchwycenie wiecznych prawd dotyczących ludzkiej natury, a w szczególności jej komicznej niedoskonałości. Według Fieldinga prawdziwym przodkiem powieści jest epika heroikomiczna, gatunek reprezentowany przez Mattea Boiardo i Ariosta, których Roland zakochany (ok. 1484) i Orland szalony (1516) kpią sobie, odpowiednio, ze średniowiecznego eposu i romansów rycerskich. Fielding widział w powieści prozatorską formę heroikomiczną przedstawiającą nie bohaterów i księżniczki, lecz ludzi wziętych z życia codziennego. Gatunek ten, choć odległy od heroicznego idealizmu, utrzymał wysoki styl epiki heroikomicznej.

W opozycji do nowożytnej powieści idealistycznej Fielding przyjął za wzorzec wspaniałą parodię epiki rycerskiej, Don Kichota Cervantesa, który w XVIII wieku nabrał nowego znaczenia i wpłynął na ewolucję gatunku. Przez długi czas po wydaniu (część 1 w 1605 roku, a część 2 w 1615 roku) Don Kichota podziwiano jako tekst wyjątkowo inteligentny i zabawny. Czytelnicy byliby jednak zaskoczeni, słysząc, że dzieło to otworzyło nową epokę 
w historii powieści. Pierwsza publiczność należycie wyczuwała, że choć podstawowym celem ataku był tu idealizm romansów rycerskich, nie było to po prostu dzieło komiczne i stanowiło prawdziwą antologię gatunków literackich i moralistycznych tamtej epoki, w tym także romansu pastoralnego, noweli, dialogu erazmiańskiego, krytyki literackiej i oratorstwa moralistycznego, które wszystkie zostały uznane za bardziej godne preferencji niż niepoprawny brak realizmu narracji rycerskich. Jako człowiek swojej epoki Cervantes wiedział, jak rozpoznać swoistą siłę każdego z gatunków narracyjnych w zakresie przedstawiania ideałów i niedoskonałości, i nie odrzucał wszystkich odmian powieści idealistycznej. Przeciwnie, autor Don Kichota należał do grupy pisarzy z przełomu XVI i XVII wieku, którzy krytykowali rycerskie opowieści właśnie za to, że preferowały idealizm odkrytych wtedy na nowo powieści greckich. W końcu Cervantes zakończył karierę Cierpieniami Persilesa i Sigismondy (1617), chrześcijańską adaptacją Opowieści etiopskiej, z której był niezmiernie dumny. Dopiero później, w XVIII wieku, wraz z pojawieniem się zaczarowania wnętrza i nowej powieści idealistycznej przeciwnicy idealizmu, a zwłaszcza Fielding i współczesny mu Tobias Smollett, nadali Don Kichotowi utrzymany następnie przez tę powieść status przodka powieści ironicznej, sceptycznej i antyidealistycznej.

Odtąd przyjmowano, że Don Kichot naucza, iż istoty ludzkie nie mogą wycofywać się ze świata; że nasze korzenie nie tkwią w niebie powieści idealistycznych, lecz w ziemi naszej śmiertelności; że jednostka z innego świata zmagająca się z powszechną przypadkowością i heroiczny naprawiacz zła to zwykłe wymysły i książkowe fikcje; a także, iż ideał, do którego dąży Rycerz Smętnego Oblicza, nie jest owocem boskiego natchnienia ani kodeksu rycerskiego, lecz lekturowych nieporozumień. Krytycy Richardsona, zwłaszcza Fielding, rozumieli, że autor Pameli próbował potajemnie przeszczepić powieść idealistyczną do świata życia codziennego, tak jak Don Kichot próbował wieść życie błędnego rycerza. Jednak podczas gdy uczciwy Rycerz Smętnego Oblicza otwarcie przyznaje się do przywiązania do wzorców Rolanda i Amadisa, przebiegły Richardson nie ostrzegł nas, że zmusza Pamelę do naśladowania bohaterek Heliodora i Madeleine de Scudéry. Według Fieldinga nie da się uniknąć wniosku, że Cervantes obalił koncepcję Pameli na długo przed jej wydaniem, wykazując ostatecznie, że ludzka natura nie jest zdolna udźwignąć celów wskazywanych przez literaturę idealistyczną.

Joseph Andrews (1742), a tym bardziej Tom Jones (1749) Fieldinga odrzucają subiektywny punkt widzenia i zaczarowanie wnętrza, by przywołać swych heroikomicznych i parodystycznych przodków. W przeciwieństwie do fabuł Richardsona, które zwykle mają jeden główny wątek i są zorganizowane wokół obsesyjnej struktury, podporządkowującej opowieść indywidualnej perspektywie postaci, narracje Fieldinga rozwijają wiele intryg, które w pełni rozumieją jedynie autor i czytelnik, podczas gdy wąskie pole widzenia postaci nie obejmuje pełnego rozwoju fabuły. Rozwiązanie Richardsona wyróżnia się 
psychologiczną intensywnością, nie potrafi jednak zapewnić tego, co Fielding: obiektywnego spojrzenia na przeznaczenie człowieka, którego nie można zredukować do egocentryzmu bohaterów. Odrzucenie przez Fieldinga jednostkowego punktu widzenia jest widoczne również w tym, jak narrator ocenia postaci, które generalnie działają pod wpływem słabo zracjonalizowanych impulsów i próbują ukrywać się za mało wiarygodnymi uzasadnieniami. Główny bohater poza wiedzą kogokolwiek nawiguje między szlachetnymi zasadami a postępowaniem godnym pożałowania. Jedynie narrator, posługujący się pełną elegancji ironią charakterystyczną dla epiki heroikomicznej, odgaduje jego słabość i obnaża ją z pobłażaniem w głosie.

Fielding łączy w jedną dużą rolę twórcę-narratora kierującego wielowątkową intrygą, mądrego komentatora, ujawniającego rozziew między chełpliwymi wypowiedziami postaci a ich nagannym często postępowaniem, a także krytyka literackiego, który wyjaśnia sensy dzieła. Jako bezstronny i nieco zdeprymowany obserwator postaci, których słabości ujawnia, Fielding nie cofa się przed uzupełnianiem opowieści mądrościami często równie ironicznymi jak narracja opowiadająca o wydarzeniach. Twórcy-narratora-komentatora, który posiada łatwą do rozpoznania fizjonomię moralną i decyduje o moralnym kursie opowieści, nie sposób zredukować do roli zwyczajnego narratora, ponieważ nie ogranicza się on jedynie do zaprezentowania historii, lecz otwarcie przyjmuje rolę organizatora i twórcy narracji. Jego głosu, który z taką samą jowialnością konwersuje o komedii ludzkiej i rzemiośle literackim, nie można nazwać inaczej jak głosem autora: tego, który tworzy opowieść i sprawuje nad nią kontrolę, konstruuje i komentuje, zapewnia jej moralną i artystyczną równowagę i przekazuje ją własnymi słowami.

Tak określony autor zawsze był obecny w powieściach - choć bywał bardziej lub mniej widoczny. U Fieldinga mamy jednak do czynienia z bezprecedensową promocją tej roli, z prawdziwym namaszczeniem autora w reakcji na to, jak nowożytne powieści idealistyczne wzmocniły narracyjny i moralny autorytet postaci. Fieldingowska promocja autora doprowadziła do powstania nowej relacji między głosem narracyjnym a fikcyjnym światem i wyznaczyła początek długiej rywalizacji między twórcą a bohaterem, którzy przez następne półtora stulecia będą walczyć o kontrolę nad tekstem narracyjnym.

\section{Mnożenie form narracyjnych}

Tristram Shandy (1760-1767) Laurence'a Sterne’a oraz Kubuś Fatalista i jego pan (1773-1775?) Denisa Diderota skorzystali z lekcji Fieldinga, chociaż sięgają korzeniami do tradycji narracji o charakterze parodystycznym i burleskowym (powstających między XVI a XVIII wiekiem), które świadomie odrzucają konwencje mimetyczne i maksymalizują czystą zabawę związaną ze snuciem 
opowieści. François Rabelais, Charles Sorel i Jonathan Swift to najbardziej znane przykłady. W ramach tej tradycji należy odróżnić dzieła niemożliwe do zaklasyfikowania zarówno ze względu na gatunek, jak i na sposób przedstawiania (Pantagruel i Podróże Guliwera) od ludycznych powieści, których celem jest wykorzystanie rozmaitych technik prozatorskich w żartobliwym tonie kosztem klarowności narracji (Przygody Francjona). Tristram Shandy i Kubuśs Fatalista należą do tej drugiej kategorii, jednak nie da się ich w pełni zrozumieć poza kontekstem sporu między nowym idealizmem Richardsona i Rousseau a ironicznym sceptycyzmem Fieldinga.

Podczas gdy Fielding krytykował nowożytną powieść idealistyczną za to, że była zbyt nierealistyczna, powieść gotycka odrzucała ją z przeciwnego powodu, twierdząc, że faworyzuje ona uważną obserwację natury, lekceważąc możliwości wyobraźni. Wymyślona przez Horacego Walpole’a, którego Zamczysko $w$ Otranto (1765) posłużyło za wzór dla Ann Radcliffe, Matthew Lewisa i wielu innych pisarzy, powieść gotycka odwróciła się od rzeczywistości empirycznej, aby zaangażować się w otwarte, niepohamowane celebrowanie skrajnych postaci fikcjonalnego nieprawdopodobieństwa. Gatunek ten, dążąc do odrodzenia rycerskich opowieści, przywołał na powrót zamki, wieże i lochy w nadziei, że wywrze na czytelnikach mocniejsze wrażenie i zrobi to bardziej bezpośrednio, niż kiedykolwiek zdołali to uczynić Richardson lub Rousseau. W imię wyobraźni gotycka sceneria kwestionowała osiągnięty nie tak dawno obiektywizm świata społecznego i fizycznego, przywracając wcześniejszą symboliczną funkcję świata jako więzienia duszy.

Powieść gotycka wprowadziła także nowy typ bohatera: demoniczną postać, zdecydowanie złowrogą i mającą nieograniczony zapas energii. Bohater ten był z pewnością pomyślany jako odpowiedź na zaczarowanie wnętrza i ideę, że cnota - choć bierna - jest siłą niewzruszoną. Zderzenie nowożytnego idealizmu z tendencjami przeciwnymi sprawiło, że osiemnastowieczna powieść zaczęła prezentować niezłomność i energię jako cechy wzajemnie się wykluczające. Na początku stulecia jedynymi postaciami kipiącymi energią byli złodzieje, łajdacy i kobieciarze, tacy jak Roderick Random, Tom Jones czy Lovelace. Później powieść gotycka odarła piękne dusze z quasi-nadprzyrodzonej mocy, jaką obdarzyły je dzieła idealistyczne, i wystawiła bezbronne na żer ich wrogów.

Także powieść obyczajowa, będąca przedłużeniem linii powieści łotrzykowskich i Fieldinga, jest powiązana z idealizmem Richardsona. Podczas gdy Expedition of Humphry Clinker Tobiasa Smolletta jest zakorzeniona w pikarejskiej ironii, Evelyna (1778) Fanny Burney, która przedstawia krytyczny obraz Londynu widzianego oczami niewinnej, wielkodusznej, młodej kobiety z prowincji, łączy satyrę społeczną z nowożytnym idealizmem. Kolejny podgatunek, powieść sentymentalna, której przykładem jest Pleban z Wakefieldu Olivera Goldsmitha, łagodzi charakterystyczny dla idealizmu brak prawdopodobieństwa, kreując realistyczną scenerię, bohaterów cnotliwych, lecz nie wzniosłych, sytuacje trudne, ale nie tragiczne, i skutki moralne pożądane, choć nie oszałamiające. 
W Cierpieniach mtodego Wertera (1774) Goethe kontynuuje wysiłki wcześniejszych pisarzy, usiłując pogodzić zaczarowanie wnętrza z psychologicznym realizmem, jednak odbywa się to kosztem całkowitego poświęcenia siły postaci. Nieugiętość wielkich heroin Richardsona, która w powieści sentymentalnej została sprowadzona do zwykłej roztropności, tu zostaje zredukowana do godnej pożałowania słabości. Niezdolność Wertera do działania pełni ważną funkcję narracyjną: zapewnia opowieści jedność akcji i umożliwia syntezę cech tragicznej noweli i narracji elegijnych. Cierpienia..., podobnie jak nowela, przedstawiają ograniczoną przestrzeń i liczbę postaci, a także niemożliwy do rozwiązania konflikt między namiętnością a małżeństwem, podczas gdy liryczny ton, brak zdecydowanego działania i rezygnacja głównego bohatera przypominają narracje elegijne. W przypadku Wertera szlachetność duszy jest jedynie jej subiektywnym, poetyckim stanem pozbawionym namacalnych, zewnętrznych konsekwencji. W ten sposób moc nowożytnego idealizmu ustępuje przed magią romantyzmu. To w istocie zwiększa wiarygodność opowieści o Werterze, bowiem czymś znacznie bardziej naturalnym jest uczestniczyć w jego próżnych marzeniach na jawie niż uwierzyć w kolosalną siłę moralną heroin Richardsona i Rousseau.

Cierpienia mtodego Wertera sygnalizują pojawienie się nowego, pesymistycznego idealizmu, który uznaje zarówno wielkość wybranych dusz, jak i niemożność ich pogodzenia ze światem. Takie dzieła, jak Pawet $i$ Wirginia Bernardina de Saint-Pierre'a (1787), Hyperion Friedricha Hölderlina (1799), Atala François-René de Chateaubrianda (1801) czy Korynna Madame de Staël (1807), biadają nad siłami natury i historii, które sprzysięgają się, by pokonać wspaniałe, lecz bezbronne dusze.

\section{Dziewiętnaste stulecie: powieść osiaga szczyt swej chwaty}

Dziewiętnaste stulecie utrzymało przy życiu nowożytny idealistyczny projekt połączenia reprezentacji pięknej duszy z realnością świata. Powieści tego okresu stawiają na pierwszym planie społeczny i historyczny realizm przedstawianych konfliktów. Powieść osiemnastowieczna sprowadziła piękną duszę na ziemię, zachowując kontrast między jej wspaniałością a otoczeniem. Powieści dziewiętnastowieczne, zajmujące się zakorzenieniem jednostki w społeczności, badały powiązania między jednostką a społeczeństwem, przedstawiając je nie jako generalne i względnie jednolite, lecz raczej jako precyzyjną i zróżnicowaną wewnętrznie sieć społecznych i historycznych zależności.

To, iż niemal wszyscy dziewiętnastowieczni powieściopisarze przykładali tak znaczną wagę do społecznego i historycznego wymiaru świata przedstawionego, nie oznaczało jednak, że odwrócili się od sporu między nowożytnym idealizmem a sceptycyzmem moralnym. Dziewiętnastowieczni zwolennicy 
idealizmu wkładali dużo pracy w to, by znaleźć dla pięknych dusz jakieś wiarygodne miejsce w sercu rzeczywistości empirycznej. Poszukując przekonujących przykładów moralnej siły i piękna, pisarze ci przeczesywali rzeczywistość gęstym grzebieniem, chcąc znaleźć przykłady cnoty pogrzebane w zagmatwanej przeszłości, zagubione w egzotycznych krajach lub uwięzione w labiryncie współczesnego społeczeństwa. Równie aktywni byli przeciwnicy idealizmu. Niektórzy z ironiczną dobrotliwością portretowali społeczne wcielenia moralnej niedoskonałości, natomiast inni z mieszanką życzliwości i surowości penetrowali pułapki subiektywizmu. Najbardziej gorliwi z oponentów idealizmu, twierdząc, że tworzy on miraże mające zamaskować naszą moralną deprawację, starali się je rozproszyć i ukazać potworną prawdę o kondycji ludzkiej. W koń$\mathrm{cu}, \mathrm{w}$ drugiej połowie stulecia, kilku wielkich pisarzy zdołało stworzyć nowe syntezy idealizmu i antyidealizmu.

\section{Idealizm, antyidealizm i środowisko społeczne}

Odrodzona przez romantyczny pesymizm tradycja idealistyczna musiała wreszcie przyznać, że trudno jest usytuować ideał we współczesnym, prozaicznym świecie. Jednak zamiast zaakceptować nieuchronną klęskę heroicznych dusz jej reprezentanci zaczęli odkrywać inne społeczeństwa i epoki, w których rzeczywiście kwitł heroizm. Historyczne powieści Waltera Scotta rozwiązały wewnętrzny problem gatunku - wiarygodność wspaniałej duszy - wykorzystując gwałtowny rozwój historiografii, jaki dokonał się na przełomie XVIII i XIX wieku. Wielką innowacją Scotta było wprowadzenie postaci, które cechowała niezłomność i energia wymagane przez powieść idealistyczną, a także uwiarygodnienie ich za pomocą stosownych uzasadnień historycznych. Ponieważ zdaniem Scotta szlachetność duszy zakorzeniona jest w archaicznych zwyczajach państw walczących, zasadne jest wysławianie jej w pierwotnych realiach historycznych, przy jednoczesnym uznaniu jej oderwania od moralnych wymogów współczesnego świata. Począwszy od Waverleya (1814), w którym awanturniczy duch szkockich górali przeciwstawiony zostaje współczesnej roztropności głównej postaci Anglika, powieść historyczna Scotta zdobyła sobie dwa rodzaje czytelników: tych, którzy lubili czytać o wyjątkowych czynach postaci godnych podziwu, i tych, którzy nie mieli zaufania do literackiej przesady.

Badając zmienność i brak ciągłości, będące wytworem historii, geografii i różnic klasowych, Scott otworzył przed prozą narracyjną ogromny obszar tematyczny. Późniejsze powieści nie musiały się już koncentrować na uniwersalnych, idealnych normach, lecz mogły eksplorować nieprzebraną różnorodność normatywnych powiązań rządzących rozmaitymi społecznościami. To z kolei oznaczało, że fundamentalne pytanie aksjologiczne - jeśli kodeks moralny stanowi inherentny element naszego świata, to dlaczego tak często jest 
lekceważony, a jeśli nie, to dlaczego tak skwapliwie się go uznaje - należało odtąd zadawać wyłącznie w odniesieniu do określonych społeczności. W konsekwencji czytelnicy Scotta zakorzenieni w spokojnej, prozaicznej cywilizacji mogli zasadniczo akceptować heroizm czasów minionych, a jednocześnie zachowywać wobec niego całkowitą obojętność.

Ponieważ zatem powieść historyczna musiała uwzględniać historyczną zmienność obyczajów i wartości, pisarze pragnący przedstawić wielkość prawdziwie uniwersalną, musieli pośród mnogości kodów rządzących istotami ludzkimi odkryć te, które rzeczywiście przekraczają granice określonych społeczeństw. Najbardziej udaną próbę wpasowania w ramy nowożytnej powieści historycznej fabuły o uniwersalnej doniosłości zawdzięczamy Alessandrowi Manzoniemu. Powieść Narzeczeni (1827), nowożytny remake Opowieści etiopskiej, przedstawia zmienne koleje losu dwojga młodych kochanków, których niezachwiana wierność zwycięża wszelkie przeciwności. Dwoje dzielnych wieśniaków, Renzo i Lucia, doświadcza prześladowań ze strony miejscowego pana, jednak podobnie jak bohaterów powieści greckich chroni ich bóstwo i jego kościół. Ich historia jest ilustracją liberalnej, wigowskiej teorii historii, która nadejście nowożytnej wolności przypisuje rozległemu projektowi opatrzności wpisanemu przed wiekami w cnoty głoszone przez chrześcijaństwo.

Podobny projekt realizuje powieść egzotyczna, poszukująca szlachetności na obszarach (i wśród narodów) nietkniętych współczesną cywilizacją: u amerykańskich Indian w powieściach Jamesa Fenimore’a Coopera, na Kaukazie Lermontowa i Tołstoja, w Italii Stendhala i Lamartine'a czy w Hiszpanii Mériméego. Podobnie powieść regionalna odkrywa szlachetne dusze na biednych, odizolowanych od reszty świata terenach, na których w tajemnicy przetrwała archaiczna niewinność, czego przykładem są nowele Adalberta Stiftera oraz La mare au diable François le Champi czy Fadette George Sand. Idealistyczna powieść społeczna odnajduje cnotę pośród przedstawicieli klas niższych. W Nędznikach Hugo odkrywa wewnętrzne piękno w ludziach należących do społecznych nizin: w skazańcu Jeanie Valjeanie i w prostytutce Fantynie. Powieść o dzieciństwie przedstawia wiek moralnej niewinności i siły: w Oliverze Twiście Dickens sławi czystość porzuconego dziecka, a w Matej Dorrit bardzo młodej dziewczyny, która jeszcze niedawno była dzieckiem.

Balzac skupił się na odmiennym pejzażu: na współczesnym społeczeństwie jako całości. Wykorzystując wprowadzoną przez Waltera Scotta metodę dzielenia ludzkości na wiele środowisk społecznych i historycznych, podjął imponujące studium ludzkiej wielkości i nędzy. W konsekwencji w powieściach Balzaka przerysowane postaci są, można powiedzieć, bardzo wyspecjalizowane. Są wśród nich wierni, pogodzeni z losem kochankowie, tacy jak Madame de Beauséant w Ojcu Goriot, kipiący energią dobroczyńcy w Historii trzynastu, wielcy artyści, tacy jak Józef Bridau w Kawalerskim gospodarstwie czy Daniel d'Arthez w Straconych ztudzeniach, a także filantropi, tacy jak doktor Benassis w Lekarzu wiejskim. Siła postaci ujawnia się jedynie w relacji do 
określonej domeny społecznej. Ponieważ celem Balzaka jest przedstawienie całego wachlarza typów ludzkich, obok swych bohaterów portretuje także upadłe anioły, wśród których najbardziej znany jest Lucjan de Rubempré, główny bohater Straconych ztudzeń. Współczesne życie, które, jak się okazuje, szczególnie obfituje w brzydotę i głupotę, wydala z siebie wiele podłych, odpychających postaci, takich jak kanonik Troubert w Proboszczu z Tours, kuzynka Bietka w powieści o tym samym tytule czy baron Hulot z tej samej opowieści. W najniższych warstwach społecznych króluje przerażający, choć zarazem uwodzicielski Vautrin, demon Komedii ludzkiej, brat wielkich złoczyńców powieści gotyckiej - Frankensteina, potwora Mary Shelley i Heathcliffa, bohatera Wichrowych wzgórz, arcydzieła Emily Brontë.

Tradycja antyidealistyczna zgromadziła rozmaitych dalekich uczniów Fieldinga, zaczynając od tego, co można by nazwać szkołą ironii, której główni przedstawiciele, Stendhal i Thackeray, niespodziewanie na powrót zwrócili się ku swobodzie powieści łotrzykowskiej i pełnemu drwiny osiemnastowiecznemu sceptycyzmowi. Pisarze ci, skrupulatnie przestrzegający norm historycznego i opisowego realizmu, nadawali tę samą rangę zarówno historycznemu determinizmowi, jak i badaniu ludzkiego serca, które postrzegali jako stałe w każdym miejscu i czasie. W ich mniemaniu geograficzne i historyczne różnice obyczajów nie są czynnikiem w największym stopniu wpływającym na ludzkie życie, niezależnie od tego, jak bardzo wydawałyby się głębokie. Różnice tego rodzaju mogą ograniczać zakres naszego działania i wybór kariery, jednak nie kontrolują energii, która napędza jednostki i kształtuje ich los.

Podczas gdy szkoła ironii była szczególnie mocna w konstruowaniu fabuły, szkoła empatii skupiała się na samoświadomości postaci i ich wzajemnym zrozumieniu. Jane Austen, podobnie jak Fielding, nie ufała subiektywnej perspektywie, jednak nie była zdecydowana, aby interweniować we własnym imieniu i obalać błędne przekonania. Zamiast tego wykorzystywała mowę pozornie zależną - narzędzie stylistyczne, które wyraźnie sugeruje zawodność subiektywnego punktu widzenia. Interioryzacja fabuły, a także staranny zapis opinii postaci o nich samych i osobach z ich otoczenia zdominowały powieści psychologiczne schyłku XIX wieku, zwłaszcza Henry’ego Jamesa, którego twórczość całkowicie oddzieliła moralny sceptycyzm od tradycji komicznej, w której był zakorzeniony. Ten okres nadał ton moralnej powagi kwestiom, które wcześniej wywoływały śmiech lub prowokowały ironię, wpisując się w ten sposób w bardziej ogólną tendencję widoczną w dziejach powieści. Dzięki temu przeobrażeniu szkoła empatii pozostawiła w spadku powieści dwudziestowiecznej bogate rozumienie najdrobniejszych drgnień ludzkiej psychiki.

Pod wpływem takich antyidealistów, jak Gustaw Flaubert, Emil Zola czy bracia Goncourtowie, krytyka idealizmu gwałtownie zwróciła się ku pesymizmowi. Pozwalając czytelnikowi zanurzyć się w umysł i zmysły postaci, technika empatii dążyła do wzmocnienia czytelniczej odrazy dla rażącej słabości moralnej bohaterów. Intymny kontakt z Emmą Bovary, Herminią Lacerteux 
czy Gerwazyną, bohaterką W matni Zoli stanowi ciągłą lekcję smutku i demoralizacji wpisanych w ludzką kondycję. W powieści przednowożytnej tego rodzaju odrażający spektakl zarezerwowany był wyłącznie dla podgatunku pikarejskiego i ograniczał się do postaci ze społecznego marginesu. Swym radykalnym zwrotem Flaubert, Zola i Goncourtowie postawili tezę, że moralna deprawacja stanowi immanentny aspekt ludzkiej kondycji. Zaczarowanie wnętrza zrodziło ostatecznie swoje przeciwieństwo, a głoszona przez nowożytny idealizm uniwersalność cnoty musiała ustąpić przed równie uniwersalnym poczuciem moralnej plajty.

\section{Syntezy: Tołstoj, Dostojewski, Fontane, Galdós}

W drugiej połowie XIX stulecia większość naprawdę znaczących powieści napisano i wydano we Francji i w Anglii. Jednak najbardziej interesujące syntezy idealizmu i antyidealizmu pochodziły $-\mathrm{z}$ jednym wyjątkiem $-\mathrm{z}$ innych krajów, których relatywna marginalność sprzyjała rozwijaniu oryginalnych stanowisk. Wspomnianym wyjątkiem była George Eliot, której Miasteczko Middlemarch przedstawia życie silnej kobiety, osiągającej szczęście po niepowodzeniu pierwszego małżeństwa. Główna bohaterka, choć opanowana i nieskazitelnie uczciwa niczym heroiny starożytnych powieści greckich, jest omylna, niemniej potrafi rozpoznać i naprawić własne błędy. Jej historia zawiera wszystkie motywy nowożytnej interioryzacji ideału: równowagę między publicznym heroizmem a prywatną, anonimową wielkością, moralne piękno istot pełnych pokory i powołanie nowożytnej powieści, by celebrować te ciche dusze, które w sekrecie podtrzymują idealizm przy życiu.

Natomiast Tołstoj był bardzo nieufny w stosunku do wszystkiego, co przypominało nowożytny idealizm. Nie lubił apoteozy jednostki, kultu indywidualnego sumienia formułującego własne prawa, a także idei, że poczucie obowiązku jest trwale wpisane w ludzkie serca. Nie uznawał roli społecznej za bezpośrednią przyczynę osobowości, widząc w niej raczej zaproszenie do modyfikacji sposobu postrzegania świata i działania. Tego rodzaju zmiany nie zachodzą jednak automatycznie. Najlepsi bohaterowie Tołstoja odrzucają gotowe normy, by walczyć - naiwnie i nieporadnie - z ciężarami nakładanymi przez społeczeństwo, jak również z wewnętrznymi sprzecznościami własnych odruchów moralnych. Olenin w Kozakach, Pierre Bezuchow w Wojnie i pokoju czy Lewin w Annie Kareninie - to wszystko piękne dusze, które nie stawiają z dumą cnoty światu przed oczy (ponieważ zdaniem Tołstoja brak skromności jest jednym z głównych symptomów moralnej porażki), lecz uparcie poszukują reguł dobrego życia. Postaci te uznają ostatecznie we własnym sercu doniosłość normy moralnej, jednak nie w formie oczywistej prawdy, którą można uchwycić przez zwykłą obserwację. Efektami wsłuchiwania się w siebie i w świat przez 
Tołstojowskie piękne dusze są wewnętrzne oświecenie lub przeczucie, a także osobista radość, niepewność lub zawód, a nie jasno sformułowane reguły i zakazy, jak to było w przypadku protagonistów Richardsona, Rousseau, Balzaka czy Dickensa. Postaci Tołstoja usiłujące pokonać własne zaślepienie i zrozumieć same siebie, wyzbyte kategorycznego języka moralności, przywodzą na myśl pełną skrupułów niewinność bohaterów pastoralnych, dla których - jak dla Bezuchowa, Lewina czy Olenina - świat jest dobroczynnym schronieniem szczerych serc poszukujących cnoty.

W twórczości Adalberta Stiftera i Theodora Fontane'a idealizm przenika do serca realnego świata jeszcze głębiej niż w powieściach ich poprzedników i współczesnych. Jednocześnie jednak moc tego idealizmu zmniejsza się do tego stopnia, że staje się ledwie dostrzegalna. W opowiadaniach Stiftera poezję serca można zwykle znaleźć u osób, którym brak fizycznej urody lub uczuciowego sukcesu - innymi słowy, u jednostek, które nie zostały wybrane przez los. Te pozornie banalne jednostki, którym życie nie oszczędza niczego, są mimo to pełne energii i dobroci. To osoby godne naśladowania, co jest szczególnie uderzające w kontekście ich nieefektownego życia. Idąc dalej w tym kierunku, Fontane dokłada wszelkich starań, by odkryć poezję ukrytą w najzwyklejszych duszach: u Effi Briest, Innstettena, Cecile, St. Arnauda - prozaicznych istot biernie podporządkowujących się wymaganiom otoczenia, nawet kiedy cierpią z powodu wewnętrznego konfliktu między poczuciem moralnego obowiązku a pragnieniem życia w życzliwym, wielkodusznym świecie. Podejmowane $\mathrm{w}$ najlepszej wierze próby przestrzegania norm społecznych nie zaspokajają skrywanych aspiracji do bezwarunkowego zaufania, pełnego oddania i namiętnej miłości. Nawet najszczęśliwsze z nich, te, które, jak się wydaje, odniosły pełny życiowy sukces, nawiedzają homeopatyczne marzenia kojarzące się z Goetheańskim Werterem. Niezależnie od tego, jak mała jest ich dawka, wystarczy niekiedy, by zabić marzącego.

Stanowisko Fiodora Dostojewskiego było przeciwne zarówno umiarkowaniu Fontane'a, jak i optymizmowi Eliot. Odrzucał powieści idealistyczne, bowiem podkreślają wzniosłość i autonomię człowieka, a antyidealizm za to, że z ludzkiej niedoskonałości czyni rozrywkę. Przeciwstawiając się starożytnej tradycji idealistycznej, Dostojewski pragnął dowieść, że wielkoduszność i niezłomność wczesnych herosów były całkowicie nierealne. Aby obalić nowożytny idealizm, który głosił zdolność wyjątkowych jednostek do tworzenia własnych praw moralnych, zaproponował przykład Raskolnikowa, studenta w imię swej autonomii zabijającego niewinną osobę. Do tej krytyki powraca w Biesach i przez postać Stawrogina dowodzi, że superman marzący o narzuceniu swych praw innym ludziom musi skończyć jako drapieżca. Jednak w przeciwieństwie do antyidealistów, dla których ludzka niedoskonałość jest niezbywalną cechą naszej kondycji, Dostojewski wierzy w możliwość doskonałości, którą w zgodzie z prawosławiem utożsamia z kontemplacyjną świętością, samopoświęceniem dla dobra innych, a nade wszystko 
z powierzeniem się Bogu. Odpowiadając tym pisarzom, których bohaterowie to piękne dusze mające pełną kontrolę nad swymi myślami i działaniami, Dostojewski opisuje swoje idealne postaci jako nieporadne ludzkie istoty, do głębi pokorne, jakby zdawały sobie sprawę z tego, że ich starania nie przynoszą im żadnej zasługi, i prosiły bliźnich o wybaczenie za to, że mimo swych wad zostały wybrane przez Boga. Jedyne piękno w zepsutym świecie to właśnie piękno tych rzadkich, naiwnych i żywiołowych odmieńców. Dostojewski dystansował się w ten sposób w równej mierze od idealizmu i antyidealizmu, nie tworząc ich syntezy. Stworzył natomiast formułę powieściową opartą na kontraście między eteryczną świętością a najbardziej odrażającymi postaciami ludzkiego upodlenia.

Pod koniec XIX wieku kolejną perspektywę wprowadzili do powieści pisarze hiszpańscy. Ich postaci są bezpowrotnie skażone pychą, a nawet odrobiną szaleństwa. Choć ich szlachetność wzmacniają ogromne zasoby energii życiowej, są to zarazem osoby psychicznie niezrównoważone, o czym świadczy nieustępliwość Fortunaty i anielska miłość Maximiliano w Fortunacie i Jacincie Benita Pérez Galdósa, a także świętość tytułowego bohatera Nazarina tego samego autora. Podobną tendencję widać w udręczonej kobiecości Any Ozores z Regentki Leopolda Alasa. Sprzymierzenie szaleństwa z idealizmem to oczywiście wpływ Cervantesa, z kolei wspomniani pisarze na nowo ożywiają i modernizują Don Kichota.

Innym elementem głęboko zakorzenionym w tradycji hiszpańskiej prozy jest przepaść oddzielająca postaci dotknięte szaleństwem od ich społecznego otoczenia. Podobnie jak pikaro, którego nieustannie prześladuje pech, Maximiliano Rubin żeni się z piękną Fortunatą, która jednak na zawsze pozostaje niedostępna; Fortunata łączy się ponownie z ukochanym Juanitem Santa Cruzem jedynie po to, by za jego sprawą cierpieć jeszcze bardziej; Ana Ozores znajduje ostatecznie zmysłową miłość, ale nie osiąga szczęścia. W zakresie, w jakim te postaci rozumieją swoje wyobcowanie w świecie, dobrowolnie akceptują tę ryzykowną sytuację, a nawet na zasadzie psychologicznego odwrócenia, któremu sprzyja stabilność tradycyjnych społeczeństw, często czują się jak w domu w atmosferze całkowicie niesprzyjającej ich aspiracjom. Do ich niedoli, pokrewnej tragedii, dodano w ten sposób coś w rodzaju komicznego współsprawstwa tych, którzy zostali wykluczeni, i świata, który ich dręczy. Postaci hiszpańskich powieści, jednocześnie wzniosłe i śmieszne, dążą do urojonej autonomii. Ich pełne pasji dążenie domaga się szacunku, jednak ich porażka nie zaskakuje. Rozwianie nawet najszlachetniejszych marzeń jest w tych powieściach postrzegane jako nieunikniona zasada ludzkiej egzystencji, ponieważ każdy zakłada, że marzeń zrealizować się nie da. Protagoniści zachowują zatem wzniosłość swych ambicji nawet przy śmieszności swej porażki. 


\section{Dwudziesty wiek i powrót formalnej różnorodności}

W ostatnim trzydziestoleciu XIX wieku powieści reprezentowały całe spektrum opcji - idealizm, antyidealizm a także ich syntezę - niemniej zachowywały uderzające podobieństwo formalne. Tacy pisarze jak Henry James, którzy podążali swoim kursem, robili to na własne ryzyko, a rzadkie próbki oryginalności nieznacznie tylko naruszały generalną monotonię gatunku. Na poziomie fabuły postaci zawsze reprezentują mieszankę niedoskonałości i aspiracji moralnych. Niemal zawsze są zakorzenione w swoim otoczeniu, odchodząc od niego rzadko i niemal niezauważalnie. Na poziomie stylu autorzy poświęcali wiele uwagi szczegółom historycznym i społecznym, dbając o realizm dialogów i zapewniając czytelnikowi możliwość zmysłowego i emocjonalnego zanurzenia się w świecie postaci. Te cechy dominowały przez długi czas, jak gdyby powodzenie formuły odkrytej po tak wielu wysiłkach zniechęcało do jakichkolwiek prób jej odświeżenia.

Czy to znaczy, że debata rozpoczęta przez powieść starożytną i kontynuowana przez jej nowożytne potomstwo została zakończona? Że postęp wiedzy zredukował ostatecznie fundamentalne pytanie aksjologiczne do jego prawdziwych wymiarów: historycznego, społecznego i psychologicznego? Że na pytanie, czy świat jest naszym prawdziwym domem, udzielono konkretnej i definitywnej odpowiedzi? Bynajmniej. Równowaga, jaką powieść osiaggnęła w drugiej połowie XIX stulecia, u większości pisarzy i czytelników mogła wywołać wrażenie, że te odwieczne problemy zostały rozwiązane. Jednak już wkrótce nowe pokolenie pisarzy stanowczo zakwestionowało pozornie solidne zakotwiczenie powieści w refleksji historycznej, socjologicznej i psychologicznej.

Owo kwestionowanie ukształtowało historię powieści na przestrzeni całego XX wieku. Nową epokę zapoczątkowała fala estetyzmu obecnego już w $\mathrm{Na}$ wspak Jorisa Karla Huysmansa (1884), która osiagnę̨ła dojrzałość w Immoraliście André Gide’a (1902). Nurt ten lekceważył społeczne uwarunkowania i aspiracje moralne jednostki. Twierdził, że ponieważ mamy prawo określać własny los zgodnie z kryteriami estetycznymi, a nie moralnymi, musimy wykorzystywać świat tak, jak uważamy za stosowne. W powieściach starożytnych prawa moralne miały charakter transcendetny. Późniejsi pisarze sytuowali normy etyczne w ludzkim sercu. W kolejnym wcieleniu normy te wyrastały z kontekstu społeczno-historycznego. Estetyzm jako pierwszy odsunął na bok względy moralne, poszukując wolności od społeczeństwa i od norm.

Marcel Proust był w swoim estetyzmie bardziej umiarkowany niż Huysmans i Gide, a jednocześnie bardziej radykalny, jeśli chodzi o odrzucenie świata. Jego arcydzieło, W poszukiwaniu straconego czasu, wykorzystało wszystkie subtelności moralnego i społecznego realizmu, aby wykazać, że świat rzeczywisty zdecydowanie nie jest naszym prawdziwym domem i jedynie sztuka daje nam dostęp do pełni życia. Ten nowy rozziew między istotami ludzkimi 
a światem jaskrawo kontrastuje z dziewiętnastowiecznymi obrazami zależności jednostki od społeczeństwa. Odrzuca roszczenia norm moralnych - zewnętrznych i wewnętrznych - i deklaruje radykalną nieredukowalność jednostki do jej otoczenia.

Pokrewny, choć jeszcze bardziej posępny duch ożywia Ulissesa Jamesa Joyce'a. Podobnie jak w arcydziele Prousta bohaterowie Ulissesa pozostają obcy dla swego świata. Jeszcze bardziej niż u Prousta zanika ich zdolność do działania. W hipernaturalistycznym stylu Joyce przywołuje mnogość konkurujących ze sobą szczegółów, które domagają się naszej uwagi. Ulysses doprowadza odkrycia szkoły empatycznej do logicznych granic, odtwarzając najdrobniejsze obrazy, wrażenia i fragmenty myśli, które, jak się zakłada, tworzą strumień naszej świadomości. Niedająca się ugasić stylistyczna werwa Joyce’a i wielość szczegółów, które na pierwszy rzut oka mogą się wydawać zbędne, sugerują, że ludzkiemu umysłowi, choć wypełniony jest obrazami i dziwacznymi zestawieniami idei, boleśnie brakuje racjonalności i energii do działania. Podczas gdy Proust widział w sztuce drogę do wyzwolenia ludzkich istot z ich smutnej kondycji, Joyce wykorzystał sztukę, by tę kondycję objaśnić, lecz nie po to, by ją przezwyciężyć. Virginia Woolf i William Faulkner - każde z nich na swój sposób - uprawiali pisanie nieprzetrawione, gdzie całe partie narracji prezentuje się bez uprzedniego opracowania, które mogłoby pomóc czytelnikowi określić, jaka jest stawka przedstawianej historii. Po II wojnie światowej ten kierunek poszukiwań kontynuowała Nathalie Sarraute i inni przedstawiciele francuskiej nowej powieści.

Kolejną formą powieściową rezygnującą z misternej fabuły jest powieść eseistyczna rozwijana przez Tomasza Manna i Roberta Musila. W tym wypadku w tkankę fikcji wpleciony zostaje dyskurs filozoficzny. Rozbudowane refleksje teoretyczne dają tu w ostatecznym rozrachunku ten sam efekt, co dane zmysłowe u Joyce'a i Faulknera. W obu przypadkach czytelnicy mają wrażenie udziału w olśniewającym przedstawieniu, podczas którego tak naprawdę bardzo niewiele się dzieje. Wszyscy ci pisarze bezwiednie powracają po własnych śladach do praktyki powieści greckiej, średniowiecznej lub epizodycznej powieści łotrzykowskiej. Podobnie jak dawne dzieła teksty Joyce’a, Faulknera i Musila przedstawiają uogólnione relacje między „ja” a światem, a nie konflikty między jednostkami a normami moralnymi, co tradycyjnie czynity nowele.

W przeciwieństwie do nich Franz Kafka stosuje technikę starannej narracji z wiarygodnymi postaciami, sprecyzowanym miejscem akcji, jasno wyznaczonym tematem, dialogami podporządkowanymi potrzebom fabuły i łatwym w odbiorze stylem. Opisując świat z pozornie obiektywnego punktu widzenia, Kafka podkreśla powagę nowego rodzaju pęknięcia między człowiekiem a jego otoczeniem, a także obcość świata, która jest tego konsekwencją. Jego czytelnicy odkrywają, że więzy łączące postać ze światem zostały, praktycznie rzecz biorąc, zerwane, jednak nie - jak u Joyce'a i Musila - z powodu idiosynkrazji 
protagonisty, który w powieściach Kafki jest zawsze zwykłym człowiekiem, lecz dlatego, że pod cienką powłoką normalności świat okazuje się na pół przerażającym, na pół śmiesznym koszmarem. To nowe pęknięcie jest tak głębokie, że miłość nie może już pogodzić jednostek ze światem. W XX wieku po raz pierwszy w historii gatunku miłość i para nie zajmują już centralnego miejsca.

Przy narracyjnej prostocie Kafki na poziomie formalnym jeszcze bardziej zdecydowanie niż Joyce, Faulkner i Musil odnowił on przednowoczesną praktykę wielości epizodów odtwarzających bez końca generalną, abstrakcyjną relację między „ja” i światem. Józef K., główny bohater Procesu, który zostaje poddany niebywałej i niezrozumiałej procedurze prawnej, podobnie jak K., mierniczy z Zamku, który na próżno usiłuje zdobyć akceptację lokalnej administracji, mogą odnaleźć w przednowożytnej powieści idealistycznej swoich przodków, którzy na każdym kroku stają wobec niepojętego niebezpieczeństwa. Różnica polega na tym, że w świecie Kafki nie ma życzliwej opatrzności, która chroniłaby i ostatecznie ratowała bohaterów.

Odkryta przez autora Procesu głęboko niepokojąca warstwa rzeczywistości stała się kanonicznym tematem wielu późniejszy powieści, podobnie jak strumień świadomości wypracowany przez Joyce’a, Woolf i Faulknera w znacznym stopniu wpłynął na sposób przedstawiania jednostki w dwudziestowiecznych narracjach powieściowych. W tak zwanej powieści postmodernistycznej postaci są uwięzione w percepcyjnym i językowym chaosie własnej świadomości i stają wobec świata pozbawionego substancji, pełnego elementów nielogicznych, niewiarygodnych lub mitycznych. Nurt postmodernistyczny, którego prefiguracją były surrealizm etniczny Jeana Giono, Mircei Eliadego i Ismaïla Kadarego, a także późne powieści Alfreda Doblina, znajduje wiele rozmaitych ilustracji u Gabriela Garcíi Márqueza, Georgesa Pereca, Michela Tourniera, Thomasa Pynchona, Toni Morrison, Salmana Rushdiego, Umberta Eco, Maria Vargasa Llosy, Dona DeLillo i innych.

Rzecz jasna te trzy główne opcje - estetyzm, intelektualizm oraz przedstawienie dezorientacji psychiki i obcości świata - nie wyczerpują niezmiernie bogatej produkcji powieściowej tego stulecia. Następcy Dostojewskiego, François Mauriac, Georges Bernanos, Julien Green, Heinrich Böll i Walker Percy, jak również egzystencjaliści, Jean-Paul Sartre i Albert Camus, kontynuowali refleksję nad moralną niedoskonałością. Spadkobiercy społecznego realizmu, Roger Martin du Gard, John Galsworthy, Doris Lessing, Hans Fallada, Saul Bellow, Tom Wolfe i - w Rosji, gdzie metodę tę kultywował realizm socjalistyczny - Borys Pasternak, Aleksander Sołżenicyn i Wasilij Grossman, pozostawali wierni dostojnemu stylowi doskonalonemu przez powieściopisarzy XIX stulecia. Neoromantycy, tacy jak Marguerite Yourcenar, Thornton Wilder, Julien Gracq czy Ernst Jünger, usiłowali uchwycić przeznaczenie wyjątkowych jednostek w ich kontekście historycznym, podczas gdy spadkobiercy tradycji ironicznej i sceptycznej, John Dos Passos, Louis-Ferdinand Céline, Jarosław Hašek, Milan Kundera, Josef Škvorecki, John Barth i Philip Roth, 
z niespożytą energią przedstawiali ludzką niedoskonałość we wrogim, absurdalnym świecie.

Wszystkie wymienione podejścia są nadal żywe w epoce, gdy powieść na nowo potwierdza swe międzynarodowe powołanie. Zarówno najstarsze tradycje literackie, jak i te, które się dopiero rodzą, wybierają powieść jako sposób na potwierdzenie swej nowoczesności. Laureaci Nagrody Nobla z ostatnich pięćdziesięciu lat wywodzili się z rozmaitych krajów, lecz niemal wszyscy byli powieściopisarzami. Dezorientacja „ja” w świecie, którego niezrozumiałość akceptujemy dziś, nie tracąc przy tym w zasadzie pogody ducha, wydaje się jednym z najczęstszych tematów nowych powieści powstających na całym świecie. Przypomina to antyczną przepaść dzielącą szlachetnych bohaterów greckich powieści od niebezpiecznego, podksiężycowego świata.

Tłum. z języka angielskiego Marek Król

(C) 2002, Giulio Einaudi editore s.p.a., Torino 